\title{
Reptile diversity in a Mediterranean wetlands landscape (Alto Guadalquivir region, southeastern Spain): are they affected by human impacts?
}

\author{
Arancha de Castro Expósito ${ }^{1}$, Enrique García-Muñoz ${ }^{1}$, Francisco Guerrero ${ }^{1,2, *}$ \\ ${ }^{1}$ Departamento de Biología Animal, Biología Vegetal y Ecología. Campus de las Lagunillas, s/n, 23071 Jaén, Spain \\ ${ }^{2}$ Centro de Estudios Avanzados en Ciencias de la Tierra, Energía y Medio Ambiente. Campus de las Lagunillas, s/n, 23071 Jaén, Spain \\ * Corresponding author. E-mail: fguerre@ujaen.es
}

Submitted on: 2020, October $30^{\text {th }}$; revised on: 2021, January $20^{\text {th }}$; accepted on: 2021, February $26^{\text {th }}$

Editor: Daniele Pellitteri-Rosa

\begin{abstract}
This study was carried out to evaluate the diversity in reptile communities in wetland landscapes located in the Mediterranean region. For this, the status of the reptile populations linked to different Mediterranean wetlands in relation to the different types of land use established in the nearby drainage basins (500 $\mathrm{m}$ around the wetlands perimeter) was determined. The different types of land use were determined together with the presence/absence, abundance and size class of the different reptile species. The results showed that areas with high anthropic pressure had a lower diversity of species, as well as a less balanced community structure, that could put at risk the effective recruitment and hence the maintenance of the reptile populations in these areas. The reasons behind the decline in the reptile community are similar to those put forward for explaining the decline in amphibians in the same area.
\end{abstract}

Keywords. Aquatic ecosystems, biodiversity crisis, Mediterranean landscapes, reptiles decline.

\section{INTRODUCTION}

Species extinction is a natural process, but in recent times there has been a more general decline in biodiversity with a species extinction rate that is estimated to be higher than it might be expected (Rockström et al., 2009; De Vos et al., 2014). The decline in biodiversity has been reported by many authors, and different causes have been considered in order to understand the complexity of joining cause and effect, being human activities identified as a crucial threat (Wake and Vredenburg, 2008; Pimm et al., 2014; Ripple et al., 2019). In this process of loss of diversity, herpetological fauna is one of the groups with the highest risk of extinction (Böhm et al., 2013; Alroy, 2015). The report of the International Union for Conservation of Nature (IUCN, 2010) reflects this critical situation, indicating that $41 \%$ of the amphibians, and $28 \%$ of the reptiles evaluated are critically threatened. As with other vertebrate groups, the main reasons behind decline are climate change (Foufopoulos et al., 2011), destruction and alteration of their habitats (Lizana and Barbadillo, 1997; Wake and Vredenburg, 2008), ecosystem pollution (Sparling, 2003; Sparling et al., 2015) or the introduction of allochthonous species (Pleguezuelos, 2002), among others.

In the Iberian Peninsula there are 56 species of reptiles (Márquez and Lizana, 2002). One of the most important threats to these species is the destruction of habitats, as a consequence of the mechanization of the agroecosystem since the Industrial Revolution (Ceacero et al., 2007). The establishment of monocultures, due to intensive agriculture, has led to a homogenization of the ecosystem, characterized today by simplistic mosaic models, which has caused a reduction in biodiversity 
and to the loss of natural habitats (Guerrero et al., 2006; García-Muñoz et al., 2010, 2016). This simplification of the agroecosystems has been widely linked to the excessive use of agrochemicals that are endangering many species (Sparling et al., 2000; Mann et al., 2009; Böll et al., 2013; García-Muñoz et al., 2019). In fact, many species of reptiles live in highly specific environments, have very restricted distributions and population growth to very slow rates (Pleguezuelos et al., 2002). Accordingly, the presence of some species of reptiles or the state of their populations will depend, among other factors, on the characteristics of the species and to what extent the habitats have been disturbed (Pleguezuelos, 2002).

Therefore, the aim of this research was to determine the status of the reptile populations in different wetlands of the Alto Guadalquivir region (Andalusia, south of Spain), in connection to the different types of land use established in the surrounding drainage basins. The hypothesis in this study was that the wetlands in which a greater number of habitats were conserved in their drainage basins would have reptile populations with higher diversity and abundance compared to those in which intensive monoculture had been established. In order to test this hypothesis, we proceeded to (i) determine the different types of land use in the drainage basins of each wetland; (ii) determine the presence/absence, abundance and size structures of the different reptile species in each wetland under study; and (iii) determine how the conservation status of the wetland drainage basin influenced reptile communities. The results from this research could enable us to propose conservation measures to be implemented for the reptile species present in the wetlands.

\section{MATERIALS AND METHODS}

Study area

The study was conducted in the Alto Guadalquivir (Andalusia), a region located in the southeast of the Iberian Peninsula. This area has a complex geological history and is ideal scenario for herpetological studies since it has both Iberian-North African and Baetic endemisms and species of Atlantic origin (Ceacero et al., 2007). The study area is characterized by three geological units: the depression of the Guadalquivir river with its tributaries, which has had a long history of anthropization, as well as two mountainous units, Sierra Morena to the north and Baetic mountains ranges to the south and east of the province (Vera, 1994). Due in large part to this complex geological history, this last region displayed the highest species richness in terms of reptiles, with a total of 39 species, which is higher than the surrounding regions (Salvador and Pleguezuelos, 2002; Ceacero et al., 2007).

Three types of wetlands can be classified based on the extent of the alteration of their drainage basins (García Muñoz

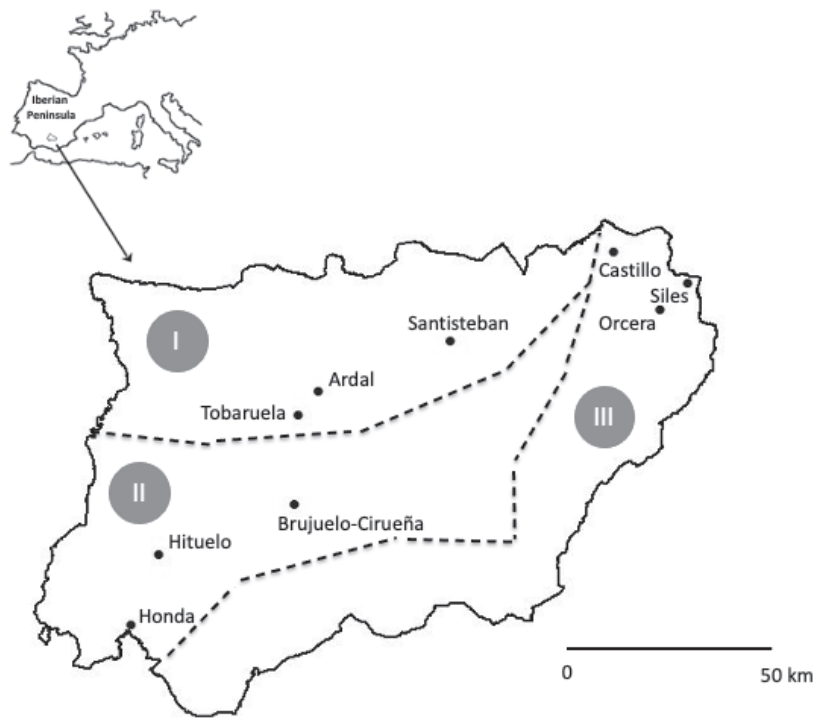

Fig. 1. Geographical location of the study area in southern Spain and the nine wetlands in the Alto Guadalquivir region. These wetlands are representative of the three zones presented in the study area: (I) Sierra Morena; (II) the Guadalquivir valley; and (III) Baetic mountain ranges.

et al., 2010, 2016; Gilbert et al., 2014, 2017): (i) those that have been greatly altered and have a very high level of human activities, situated in the valley of the Guadalquivir river; (ii) those that have been partially conserved in the areas of the Sierra Morena and there is a low level of human activities; and (iii) those that have been conserved, such as the wetlands belonging to the Baetic mountain ranges. In this study, nine wetlands representative of the three zones in the study area in the Alto Guadalquivir region have been investigated (Fig. 1): Sierra Morena (Ardal, Tobaruela and Santisteban), the Guadalquivir Valley (Honda, BrujueloCirueña and Hituelo) and the Baetic mountain ranges (Castillo, Siles and Orcera). Although we are aware that the number of wetlands per area is limited, the value of this study is precisely to address three different areas and to be able to make comparisons between them. Notwithstanding, since the selected wetlands are the most representative of each zone (García-Muñoz et al., 2010; Gilbert et al., 2014, 2015, 2017), in the future this study should be expanded to a greater number of wetlands.

\section{Data collection}

For each area, a sampling buffer zone of $500 \mathrm{~m}$ from the shoreline of the wetland included in the drainage basin was established. We characterized the different land uses in the area according to the habitat classifications of the Spanish Society of Ornithology (SEO, 2008). For each habitat category, the surface (in hectares) was obtained within QGIS 2.14 software environment (see Table 1). A bibliographic review on the reptile species present in each wetland was also carried out $\left(\mathrm{S}_{\text {Ref }}\right.$; Pleguezuelos et al., 2002; Ceacero et al., 2007; AHE database, 2016). 
Table 1. Percentage land use in the study wetlands following the habitat proposed by SEO (2008).

\begin{tabular}{|c|c|c|c|c|c|c|c|c|c|}
\hline Habitat & Ardal & Tobaruela & Santisteban & Honda & $\begin{array}{c}\text { Brujuelo- } \\
\text { Cirueña }\end{array}$ & Hituelo & Castillo & Siles & Orcera \\
\hline Wetland surface area & 4.32 & 1.20 & 3.37 & 10.49 & 4.46 & 3.86 & 0.15 & 0.32 & 0.03 \\
\hline Olive crops area & 1.128 & 40.77 & 12.03 & 131.36 & 122.26 & 102.30 & 24.67 & -- & -- \\
\hline Rainfed crops area & 19.57 & 27.10 & 69.86 & -- & 12.21 & -- & 37.91 & -- & -- \\
\hline Roads and tracks length $(\mathrm{m})$ & 4821.1 & 5967.98 & 6745.08 & 4021.97 & 1785.43 & 2650.54 & 2584.13 & 1029.82 & 1937.59 \\
\hline Urbanization area & 22.58 & 17.33 & 8.92 & -- & -- & 0.44 & -- & -- & -- \\
\hline Scrubland area & -- & 10.85 & -- & 6.87 & 3.33 & -- & 11.14 & -- & -- \\
\hline Holm oak and cork oak forest area & 68.86 & -- & -- & -- & -- & -- & 2.58 & -- & -- \\
\hline Pines forest and grassland area & -- & -- & -- & -- & -- & -- & -- & 76.69 & 70.13 \\
\hline Altitude (m a.s.l.) & 400 & 363 & 637 & 446 & 458 & 476 & 780 & 1280 & 1270 \\
\hline
\end{tabular}

For field data collection $\left(\mathrm{S}_{\mathrm{Obs}}\right)$, the same procedure was replicated (three times regarding each wetland) for all samplings from April to July 2016 (concerning the season in which there is the highest reptile activity on this area). Different timeconstrained searches were used (see Hutchens and DePerno, 2009): (i) linear transects, covering all the land uses present in each drainage basin of each wetland, within the delimited area of study; (ii) standardized road searches during twilight hours; and (iii) sampling based on fixed points for 30 minutes in each one, with a more intensive search of possible refuges, such as stones, logs or abandoned farmhouses, in all the habitats that were in each wetland. All the individuals registered were identified, their abundance was counted, and each individual was classified into the three size ranges: juvenile, sub-adults and adults. The authors are aware that the detection of adults, subadults and juveniles is not the same. However, as the sampling strategy is the same and the detection level is similar between wetlands, we consider that the data obtained are totally valid at a comparative level between wetlands. For aquatic reptiles (Mauremys leprosa, Natrix maura and $N$. natrix) we chose to use a visual detection method and fixed points sampling (three fixed points on the shores of each wetland). Attending to surface area of the ponds, we chose three points because the entire wetland could be observed as a whole and thus avoiding an underestimation of the aquatic species. This was made to avoid possible translocations of diseases among study wetlands, because there have been verified cases of chytridiomycosis in the wetlands of the Baetic mountain ranges (Bosch and González-Miras, 2012), and that reptiles may be potential vectors of this disease (Kilburn et al., 2011).

\section{Statistical analysis}

To evaluate the relationship between land uses and the reptile species in each wetland, multivariate analyses were carried out with the CANOCO program (v 5.03). First, a Segmented Correspondence Analysis (DCA: Detrended Correspondence Analysis) was performed to calculate the gradient length. When the value of the gradient length is less than 1.5 , as was our case, an RDA is recommended (Iturrondobeitia et al., 2004). The
RDA (Redundancy Analysis) is based on a constrainer that explains the variation in species composition by environmental variables (Ramírez-González, 2005). Similarity Percentage Analysis (SIMPER, PRIMER v. 5.2) was subsequently used to identify the features of the species of each geographic group of wetlands (Clarke and Warwick, 2001): group 1 (Sierra Morena wetlands), group 2 (Guadalquivir valley wetlands), and group 3 (Baetic mountain ranges wetlands). Both statistical analyses were carried out with all the species registered in the wetlands under study $\left(\mathrm{S}_{\text {total }}=\mathrm{S}_{\mathrm{Obs}}+\mathrm{S}_{\mathrm{Ref}}\right)$.

Finally, the Simpson's dominance index (Simpson, 1949) was calculated just using the observed abundance data $\left(\mathrm{S}_{\mathrm{Obs}}\right)$ in the three types of wetlands previously mentioned. Simpson's index measures the probability that two individuals randomly selected from a sample will belong to the same species. Diversity values can also be obtained after subtracting by one the value given in Simpson's dominance.

\section{RESULTS}

Table 2 shows the fifteen species of reptiles that have been observed in the wetlands under study $\left(\mathrm{S}_{\mathrm{Obs}}\right)$ and five more species that were within the study area following the bibliographic review $\left(S_{\text {Ref }}\right)$. The DCA results showed that the three first axes explained $72.65 \%$ of the variation. The results of the multivariate RDA analysis showed the relationship between land use and species (Fig. 2). Moreover, in the centre of the graph a group of more generalist species, such as Malpolon monspessulanus, Timon lepidus, Psammodromus algirus or Rhinechis scalaris could be seen; while other groups with more specialist species, such as Vipera latastei, Coronella girondica, Natrix natrix or Chalcides bedriagai, were located far from the centre of the graph. Siles and Orcera were locations in the plot that were farthest from rainfed crops, roads, olive groves and built-up land. Therefore, they appeared as less degraded and more inaccessible. Honda, Santisteban, Hituelo, Tobaruela and Brujuelo-Cirueña wetlands were closely linked 
Table 2. Presence registered in the field sampling $\left(+, \mathrm{S}_{\mathrm{obs}}\right)$, presence registered by bibliographic data $\left(+^{*}, \mathrm{~S}_{\text {ref }}\right)$ and absence $(-)$ of the reptile species in the study wetlands.

\begin{tabular}{|c|c|c|c|c|c|c|c|c|c|}
\hline Species & Ardal & Tobaruela & Santisteban & Honda & $\begin{array}{c}\text { Brujuelo- } \\
\text { Cirueña }\end{array}$ & Hituelo & Castillo & Siles & Orcera \\
\hline Acanthodactylus erythrurus & $+^{*}$ & $+^{*}$ & - & - & - & - & - & - & + \\
\hline Podarcis vaucheri & - & $+^{*}$ & - & $+^{*}$ & - & + & $+^{*}$ & $+^{*}$ & + \\
\hline Psammodromus algirus & + & + & + & + & + & + & + & + & + \\
\hline Psammodromus hispanicus & $+^{*}$ & - & - & - & + & - & - & + & $+^{*}$ \\
\hline Tarentola mauritanica & + & $+^{*}$ & + & + & + & + & + & + & + \\
\hline Timon lepidus & + & + & $+^{*}$ & + & + & $+^{*}$ & + & + & + \\
\hline Blanus cinereus & $+^{*}$ & + & - & $+^{*}$ & - & - & - & $+^{*}$ & $+^{*}$ \\
\hline Coronella girondica & - & - & - & - & - & - & - & + & - \\
\hline Hemorrhois hippocrepis & $t^{*}$ & $t^{*}$ & - & + & - & + & $t^{*}$ & - & $t^{*}$ \\
\hline Malpolon monspessulanus & $t^{*}$ & + & $t^{*}$ & + & + & + & + & $t^{*}$ & $+^{*}$ \\
\hline Rhinechis scalaris & $+^{*}$ & + & $+^{*}$ & $+^{*}$ & + & $+^{*}$ & $+^{*}$ & $+^{*}$ & $+^{*}$ \\
\hline Chalcides striatus & $t^{*}$ & - & + & - & $+^{*}$ & - & $t^{*}$ & + & + \\
\hline Chalcides bedriagai & + & - & - & - & - & - & - & + & - \\
\hline Mauremys leprosa & + & + & $t^{*}$ & $+^{*}$ & $t^{*}$ & + & + & - & - \\
\hline Natrix maura & $+^{*}$ & $+^{*}$ & $+^{*}$ & $+^{*}$ & - & $+^{*}$ & $+^{*}$ & $+^{*}$ & $+^{*}$ \\
\hline Vipera latastei & - & - & - & - & - & - & $t^{*}$ & $t^{*}$ & $+^{*}$ \\
\hline Macroprotodon brevis & $+^{*}$ & - & - & - & - & - & $t^{*}$ & $t^{*}$ & - \\
\hline Hemidactylus turcicus & $+^{*}$ & - & $t^{*}$ & $+^{*}$ & - & - & - & - & - \\
\hline Algyroides marchi & - & - & - & - & - & - & - & $t^{*}$ & $+^{*}$ \\
\hline Natrix natrix & - & - & - & - & - & - & - & $+^{*}$ & - \\
\hline Richness & 15 & 11 & 9 & 11 & 8 & 9 & 12 & 16 & 14 \\
\hline
\end{tabular}

to the olive groves and dry land crops, and a multitude of roads have been created in order to provide better accessibility for agricultural purposes. Ardal wetland is mostly surrounded by oak forests but is also near built-up land because a few years ago a housing estate was built nearby.

The results of the SIMPER analysis (Fig. 3) show the average contribution of each species in the three groups analysed. It can be seen how $P$. algirus, T. mauritanica, $T$. lepidus, R. scalaris, M. monspessulanus, N. maura and M. leprosa are the species that most contributed to the percentage of similarity within each group and among the three study groups. Moreover, M. leprosa could be seen in $100 \%$ of the wetlands of groups 1 and 2, but in group 3 it could only be observed in Castillo. Vipera latastei is the species that most contributed to the dissimilarity in group 3 compared to the other ones (Group 1-3: 13.24\%, Group 2-3: 10.64\%). A. erythrurus is the species that most contributed to dissimilarity in group 1 (Group 1-2: 13.41\%; Group 1-3: 7.2\%) compared to the other ones, although a juvenile was also found in Orcera.

Table 3 shows the results of the size structures in each wetland under study. In all of them an inverted pyramid has been observed, which showed there to be more adults than juveniles or sub-adults. In addition, in some wet- lands, such as Tobaruela, Honda and Brujuelo-Cirueña, there did not appear to be any recruitment; while in other ones, for example, Ardal, Castillo, Orcera and Siles, the highest number of juveniles and sub-adults were found in comparison with the other wetlands under study (see Table 3). The results of Simpson's dominance index (D) showed a gradient for group 1 (Sierra Morena; $\mathrm{D}=0.501$ ), with maximum dominance for group 2 (Guadalquivir valley; $\mathrm{D}=0.323$ ) and group 3 (Baetic mountain ranges; $\mathrm{D}=$ 0.250 ) with the maximum diversity value.

\section{DISCUSSION}

Reptiles play important ecological roles contributing to the maintenance of environmental heterogeneity (Kaczor and Hartnett, 1990) having a keystone functions in the ecosystem structure (Ashton, 2010). In fact, they tend to be strongly associated with local habitat quality and could be excellent bioindicators of the ecosystem conservation state (Pianka, 1967; Overmann and Krajicek, 1995; Crain and Guillette, 1998; Amaral et al., 2012).

Although extinction marks the end of any form of life, the speed at which a group reaches this point could 


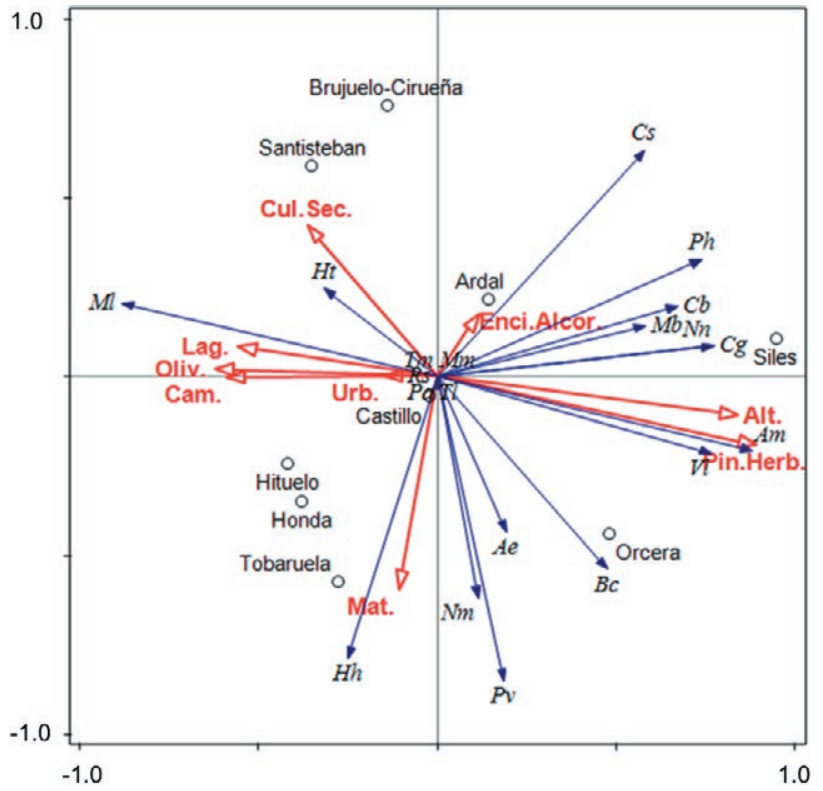

Fig. 2. Relationship of wetlands land uses and reptile species by RDA. Acanthodactylus erythrurus (Ae), Podarcis vaucheri (Pv), Psammodromus algirus (Pa), Psammodromus hispanicus (Ph), Tarentola mauritanica (Tm), Timon lepidus (Tl), Blanus cinereus $(\mathrm{Bc})$, Coronella girondica (Cg), Hemorrhois hippocrepis (Hh), Malpolon monspessulanus (Mm), Rhinechis scalaris (Rs), Chalcides striatus (Cs), Chalcides bedriagai (Cb), Mauremys leprosa (Ml), Natrix maura $(\mathrm{Nm})$, Vipera latastei (Vl), Macroprotodon brevis (Mb), Hemidactylus turcicus (Ht), Algyroides marchi (Am), Natrix natrix (Nn).

increase due to the combination of causes and effects derived from the activity of other species. As expressed in the title of this paper, the current situation of reptiles in the wetlands of the south of Iberia is reminiscent of the path taken by amphibians in the same study area (GarcíaMuñoz et al., 2010, 2016). The simplification of agroecosystems with extensive and intensive monocultures that is ever present nowadays, that impoverishes the natural ecosystem are leading to the extinction of species worldwide.

In general terms, the species richness obtained is inversely related to the rise in monocultures (olive and cereal crops), both in terms of surface expansion and intensive production. As a result, the wetlands showed greater species richness in those areas (Sierra Morena and Betic mountains) where there are fewer crops and greater inaccessibility. It can therefore be seen that wetlands related to olive groves, cereal crops, and built-up land are more accessible for humans, and, consequently, show a lower richness in reptiles. However, and eliminating the option of the existence of an intrinsic geographical gradient in the distribution of species in the study area, wetlands located in mountainous areas (Baetic mountain

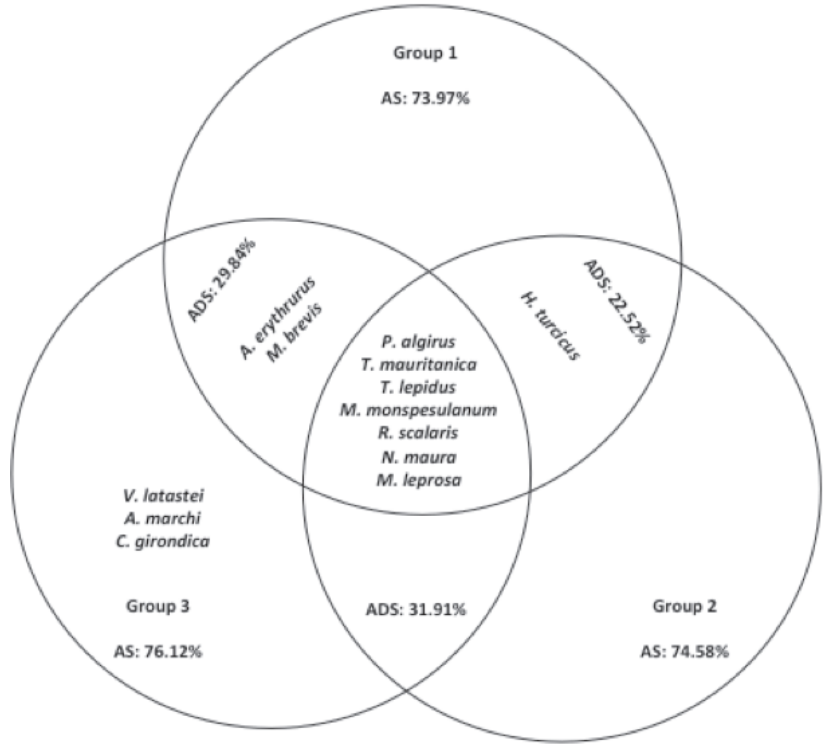

Fig. 3. Main species organization according to values of exclusivity. Typical species to each group is represented in the exclusive zone of each circle, while species shared between two groups are represented with the union of two circles. The species that appear in all three zones are in the intersection of the three circles (AS: average similitude; ADS average dissimilitude from SIMPER analysis).

ranges) showed greater species richness. As regards the different presence of species in the wetlands investigated by the study (Table 2), five of them were found in all ecosystems. These species could be used in future research to develop different biomarkers (oxidative stress, bioaccumulation, etc.) to compare the state of health of the ecosystems. However, these species could be resistance to disturbance and, hence, only indicators of severe stress. Therefore, the effects on the species most sensitive to disturbances (stenoic species), which have been shown to present a negative spatial response to fragmentation and disturbance of the landscape (Devictor, 2008), must also be taken into account to allow early detection of degradation processes.

Other research carried out in the same study area showed how complex the interaction between human activity and nature was. Specifically, García-Muñoz and Carretero (2013) studied the rate of water loss in two species of lizards (Podarcis vaucheri and Algyroides marchi) that coexisted in the same habitat but had different physiological rates. Minimal variations on a microecosystems level could have been related to their physiological capacities (such as their ability to lose water) that could have explained specific (local) extinctions (Santos and Cheylan, 2013; Ferreira et al., 2016). The establishment of a monoculture and the consequent ecological oversimplification (e.g., loss of micro-habitats with dif- 
Table 3. Species observed $\left(\mathrm{S}_{\mathrm{obs}}\right)$ and number of individuals in the three size ranges in the studied wetlands.

\begin{tabular}{|c|c|c|c|c|c|c|c|c|c|c|c|}
\hline \multicolumn{2}{|l|}{ Species } & \multirow{2}{*}{ Ardal } & \multicolumn{2}{|c|}{ Tobaruela Santisteban } & \multirow{2}{*}{$\begin{array}{c}\text { Honda } \\
--\end{array}$} & \multirow{2}{*}{$\begin{array}{c}\text { Brujuelo- } \\
\text { Cirueña }\end{array}$} & \multirow{2}{*}{$\begin{array}{c}\text { Hituelo } \\
--\end{array}$} & \multirow{2}{*}{$\begin{array}{c}\text { Castillo } \\
--\end{array}$} & \multirow{2}{*}{$\begin{array}{c}\text { Siles } \\
--\end{array}$} & \multirow{2}{*}{ Orcera } & \multirow{2}{*}{$\begin{array}{c}\text { Number } \\
--\end{array}$} \\
\hline Acanthodactylus & Adults & & -- & -- & & & & & & & \\
\hline \multirow{2}{*}{ erythrurus } & Subadults & -- & -- & -- & -- & -- & -- & -- & -- & -- & -- \\
\hline & Juveniles & -- & -- & -- & -- & -- & -- & -- & -- & 1 & 1 \\
\hline \multirow[t]{3}{*}{ Podarcis vaucheri } & Adults & -- & -- & -- & -- & -- & 1 & -- & -- & -- & 1 \\
\hline & Subadults & -- & -- & -- & -- & -- & -- & -- & -- & 1 & 1 \\
\hline & Juveniles & -- & -- & -- & -- & -- & -- & -- & -- & -- & -- \\
\hline \multirow[t]{3}{*}{ Psammodromus algirus } & Adults & 7 & 21 & -- & 14 & 26 & 4 & 16 & 14 & 52 & 154 \\
\hline & Subadults & -- & -- & -- & -- & -- & -- & -- & -- & 1 & 1 \\
\hline & Juveniles & 2 & - & -- & -- & -- & -- & -- & -- & 3 & 5 \\
\hline \multirow{3}{*}{ Psammodromus hispanicus } & Adults & -- & - & -- & -- & 1 & -- & -- & 37 & -- & 38 \\
\hline & Subadults & -- & -- & -- & -- & -- & -- & -- & -- & -- & -- \\
\hline & Juveniles & -- & - & -- & -- & -- & -- & -- & -- & -- & -- \\
\hline \multirow[t]{3}{*}{ Tarentola mauritanica } & Adults & 4 & - & 1 & -- & 5 & 3 & 2 & 1 & 1 & 17 \\
\hline & Subadults & -- & -- & -- & 8 & -- & -- & -- & -- & -- & 8 \\
\hline & Juveniles & 1 & -- & -- & -- & -- & -- & -- & -- & -- & 1 \\
\hline \multirow[t]{3}{*}{ Timon lepidus } & Adults & 4 & - & -- & -- & 4 & -- & 4 & 5 & 6 & 23 \\
\hline & Subadults & -- & 1 & -- & 1 & -- & -- & -- & 2 & -- & 4 \\
\hline & Juveniles & -- & - & -- & -- & -- & -- & 1 & 2 & 2 & 5 \\
\hline \multirow[t]{3}{*}{ Blanus cinereus } & Adults & -- & 1 & -- & -- & -- & -- & -- & -- & -- & 1 \\
\hline & Subadults & -- & - & -- & -- & -- & -- & -- & -- & -- & -- \\
\hline & Juveniles & -- & -- & -- & -- & -- & -- & -- & -- & -- & -- \\
\hline \multirow[t]{3}{*}{ Coronella girondica } & Adults & -- & - & -- & -- & -- & - & -- & -- & -- & -- \\
\hline & Subadults & -- & -- & -- & -- & -- & -- & -- & 1 & -- & 1 \\
\hline & Juveniles & -- & -- & -- & -- & -- & -- & -- & -- & -- & -- \\
\hline \multirow[t]{3}{*}{ Hemorrhois hippocrepis } & Adults & -- & - & -- & -- & -- & -- & -- & -- & -- & -- \\
\hline & Subadults & -- & -- & -- & 1 & -- & -- & -- & -- & -- & -- \\
\hline & Juveniles & -- & -- & -- & -- & -- & 1 & -- & -- & -- & 1 \\
\hline Malpolon monspessulanus & Adults & -- & 3 & -- & 1 & 2 & 1 & 2 & -- & -- & 9 \\
\hline & Subadults & -- & -- & -- & -- & -- & -- & 2 & -- & -- & 2 \\
\hline & Juveniles & -- & -- & -- & -- & -- & -- & 1 & -- & -- & 1 \\
\hline Rhinechis scalaris & Adults & -- & 1 & -- & -- & 2 & -- & -- & -- & -- & 3 \\
\hline & Subadults & -- & 2 & -- & -- & -- & -- & -- & -- & -- & 2 \\
\hline & Juveniles & -- & -- & -- & -- & -- & -- & -- & -- & -- & -- \\
\hline Chalcides striatus & Adults & -- & -- & 11 & -- & -- & -- & -- & 7 & 5 & 23 \\
\hline & Subadults & -- & -- & -- & -- & -- & -- & -- & 1 & 1 & 2 \\
\hline & Juveniles & -- & -- & 1 & -- & -- & -- & -- & 3 & -- & 4 \\
\hline Chalcides bedriagai & Adults & 1 & -- & -- & -- & -- & -- & -- & 5 & -- & 6 \\
\hline & Subadults & -- & -- & -- & -- & -- & -- & -- & -- & -- & -- \\
\hline & Juveniles & 1 & - & -- & -- & -- & -- & -- & -- & -- & 1 \\
\hline Mauremys leprosa & Adults & -- & - & -- & -- & -- & -- & 20 & -- & -- & 20 \\
\hline & Subadults & -- & 1 & -- & -- & -- & 1 & -- & -- & -- & 2 \\
\hline & Juveniles & 1 & -- & -- & -- & -- & -- & 1 & -- & -- & 2 \\
\hline Natrix maura & Adults & 1 & - & 12 & 1 & 2 & 9 & 2 & -- & -- & 27 \\
\hline & Subadults & -- & 1 & -- & -- & -- & -- & 2 & -- & -- & 3 \\
\hline & Juveniles & -- & -- & 1 & -- & -- & -- & 1 & -- & -- & 2 \\
\hline Total & Adults & 17 & 26 & 24 & 15 & 40 & 15 & 44 & 69 & 64 & 314 \\
\hline & Subadults & -- & 5 & -- & 10 & -- & 1 & 2 & 4 & 2 & 24 \\
\hline & Juveniles & 5 & -- & 2 & -- & -- & 1 & 5 & 5 & 6 & 24 \\
\hline
\end{tabular}


ferent humidity ranges, as has occurred in the Guadalquivir valley) could have brought about changes that gave rise to more complex extinction processes. This concept could have been linked with the facilitation theory, with abiotic facilitation to be specific (facilitation that is mediated through changes in the abiotic environment; Wright et al., 2017), so that oversimplifications in the agroecosystem could lead to an insufficient number of habitats, which, in turn, would bring about an alteration in the species richness. In this respect, other studies on the state of conservation of the Alto Guadalquivir wetlands (Gilbert et al., 2017) showed how intensive cultivation activities affected conservation of the diversity of wetlands. Furthermore, oversimplification in ecosystems brought about by monocultures, not only hinders the number of species and individuals, but also reduces reptile recruitment. The disappearance of natural refuges as a consequence of the management methods inherent to monocultures (whose aim is to remove any objects from the agricultural area), the indiscriminate use of herbicides and insecticides (which eradicate natural refuges and food) and the bioaccumulation and bioamplification process (Daley et al., 2014), could explain the lack of recruitment in these areas.

This study was designed in order to find out what the current status of reptiles in the Alto Guadalquivir region was. However, more studies are necessary to determine what has led to this process of decline. In order to anticipate moves in the game of extinction, we need to consider a range of environmental strategies. The first measure proposed is linked to the theory of conservation biology (Soulé, 1985; Sagoff, 2013), by maintaining biodiversity, the structure and function of ecosystems, expanding protected areas in the Sierra Morena and the Baetic mountain ranges. The second one lies within the context of the ecosystem management theory; that in the study area is related to integrated crop management to make monoculture more beneficial by recovering their biodiversity (Rey-Zamora et al., 2017). The latter measure increases heritage values, environmental sustainability and landscape values. Moreover, it enables traditional landscape planning to be recovered. These changes in agricultural strategy have been more specifically linked to a reduction in erosion, a decrease in the use of toxic substances and to a rise in land-use heterogeneity. Moreover, these actions could also promote conservation of the biodiversity of other related groups, such as amphibians (García-Muñoz et al., 2010). In addition, the third measure for consideration could be to use biomarkers developed with the species found in all the wetlands, such as P. algirus, T. mauritanica, T. lepidus, $M$. monspessulanus and $R$. scalaris.
On a final note, authors would like to indicate an issue of concern, which is the increasing popularity of leisure pursuits in areas of natural beauty where access is limited for most people. The rise in this phenomenon, without taking into account the negative effects they have on wildlife, could increase the likelihood of encountering reptiles that, apart from the aversion that these organisms arouse in some people, could lead to the re-emergence of threats to this group that have been forgotten and also give rise to new ones that have not yet been created. In the former we are referring to direct persecution of reptiles by humans (Ceríaco, 2012) and in the latter the translocation of diseases such as chytriodiomycosis, which has been detected in Baetic mountains (Bosch and González-Miras, 2012).

\section{ACKNOWLEDGEMENTS}

Authors thank Junta de Andalucía for the permission to sample reptiles in Alto Guadalquivir wetlands (permits number: 61/CV716Yb107/2016 - SVEENPP54/2016). We also thank two anonymous reviewers who have improved the final version of the manuscript.

\section{REFERENCES}

AHE database - Asociación Herpetológica Española (2016): www.herpetologica.es. [Accessed 28 Sep 2016]

Alford, R.A., Richards S.J. (1999): Global amphibian declines: A problem in applied ecology. Ann. Rev. Ecol. Evol. Syst. 30: 133-165.

Alroy, J. (2015): Current extinction rates of reptiles and amphibians. Proc. Nat. Ac. Sci. 112: 13003-13008.

Amaral, M.J., Bicho, R.C., Carretero, M.A., SánchezHernández, J.C., Faustino, A.M.R., Soares, A.M.V.M., Mann, R. (2012): The use of a lacertid lizard as a model for reptile ecotoxicology studies: part 2 - biomarkers of exposure and toxicity among pesticide exposed lizards. Chemosphere 87: 765-774.

Ashton, P.J. (2010): The demise of the Nile crocodile (Crocodylus niloticus) as a keystone species for aquatic ecosystem conservation in South Africa: the case of the Olifants River. Aquat. Conserv. Mar. Freshw. Ecosyst. 20: 489-93.

Barnosky, A.D., Matzke, N., Tomiya, S., Wogan, G.O.U., Swartz, B., Quental, T.B., Marshall, C., McGuire, J.L., Lindsey, E.L., Maguire, K.C., Mersey, B., Ferrer, E.A. (2011): Has the Earth's sixth mass extinction already arrived? Nature 471: 51-57. 
Blaustein, A.R., Han, B.A., Relyea, R.A., Johnson, P.T.J., Buck, J.C., Gervasi, S.S., Kats, L.B. (2011): The complexity of amphibian population declines: understanding the role of cofactors in driving amphibian losses. Ann. N.Y. Acad. Sci. 1223: 108-119.

Böhm, M., Collen, B., Baillie, J.E.M., Bowles, P., Chanson, J., Cox, N., Hammerson, G., Hoffmann, M., Livingstone, S.R., Ram, M., Rhodin, A.G.J., Stuart, S.N., Van Dijk, P.P., Young, B.E. et al. (2013): The conservation status of the world's reptiles. Biol. Conserv. 157: 372-385.

Böll, S., Schmidt, B.R., Veith, M., Wagner, N., Rödder, D., Weimann, C., Kirschey, T., Lötters, S. (2013): Anuran amphibians as indicators of changes in aquatic and terrestrial ecosystems following GM crop cultivation: a monitoring guideline. BioRisk 8: 39-51.

Bosch, J., González-Miras, E. (2012): Seguimiento de Alytes dickhilleni: Informe final. Monografías SARE. Asociación Herpetológica Española and Ministerio de Agricultura, Alimentación y Medio Ambiente, Madrid.

Ceacero, F., García-Muñoz, E., Pedrajas, L., Hidalgo, A., Guerrero, F. (2007): Actualización herpetológica de la provincia de Jaén. Munibe 25: 130-139.

Ceríaco, L.M.P. (2012): Human attitudes towards herpetofauna: The influence of folklore and negative values on the conservation of amphibians and reptiles in Portugal. J. Ethnobiol. Ethnomed. 8: 8.

Clarke, K.R., Warwick, R.M. (2001): Change in marine communities: an approach to statistical analysis and interpretation. PRIMER-E, Plymouth.

Crain, D.A., Guillette, Jr., L.J. (1998): Reptiles as models of contaminant-induced endocrine disruption. Anim. Reprod. Sci. 53: 77-86.

Daley, J.M., Paterson, G., Drouillard, K.G. (2014): Bioamplification as a bioaccumulation mechanism for persistent organic pollutants (POPs) in wildlife. In: Reviews of environmental contamination and toxicology, pp. 107-155. Whitacre, D.M., Ed, Springer, New York.

Devictor, V., Julliard, R., Jiguet, F. (2008): Distribution of specialist and generalist species along spatial gradients of habitat disturbance and fragmentation. Oikos 117: 507-514.

De Vost, J.M., Joppa, L.N., Gittleman, J.L., Stephens, P.R., Pimm, S.L. (2014): Estimating the normal background rate of species extinction. Conserv. Biol. 29: 452-462.

Ferreira, C.C., Santos, X., Carretero, M.A. (2016): Does ecophysiology mediate reptile responses to fire regimes? Evidence from Iberian lizards. PeerJ 4: e2107.

Foufopoulos, J., Kilpatrick, A.M., Ives, A.R. (2011): Climate change and elevated extinction rates of reptiles from Mediterranean islands. Am. Nat. 177: 119-129.
García-Muñoz, E., Carretero, M.A. (2013): Comparative ecophysiology of two sympatric lizards. Laying the groundwork for mechanistic distribution models. Acta Herpetol. 8: 123-128.

García-Muñoz, E., Gilbert, J.D., Parra, G., Guerrero, F. (2010): Wetlands classification for amphibian conservation in Mediterranean landscapes. Biodivers. Conserv. 19: 901-911.

García-Muñoz, E., Gilbert, J.D., Parra, G., Guerrero, F. (2016): Amphibian diversity as an implement for Mediterranean wetlands conservation. J. Nat. Conserv. 33: 68-75.

García-Muñoz, E., Guerrero, F., Arechaga, G., Parra, G. (2019): Does wetland watershed land use influence amphibian larval development? A relevant effect of agriculture on biota. J. Oceanol Limnol. 37: 160-168.

Gibbons, J.W., Scott, D.S., Ryan, T.J., Buhlmann, K.A., Tuberville, T.D., Metts, B.S., Greene, J.L., Mills, T., Leiden, Y., Poppy, S., Winne, C.T. (2000): The global decline of reptiles. Déjà vu amphibians. Biosci. 50: 653-666.

Gilbert, J.D., de Vicente, I., Jiménez-Melero, R., Parra, G., Guerrero, F. (2014): Selecting priority conservation areas based on zooplankton diversity: the case of Mediterranean wetlands. Mar. Freshw. Res. 65: 857871.

Gilbert, J.D., de Vicente, I., Ortega, F., Jiménez-Melero, R., Parra, G., Guerrero, F. (2015): A comprehensive evaluation of the crustacean assemblages in southern Iberian Mediterranean wetlands. J. Limnol. 74: 169181.

Gilbert, J.D., de Vicente, I., Ortega, F., García-Muñoz, E., Jiménez-Melero, R., Parra, G., Guerrero, F. (2017): Linking watershed land uses and crustacean assemblages in Mediterranean wetlands. Hydrobiologia 799: 181-191.

Guerrero, F., Parra, G., Jiménez-Gómez, F., Salazar, C., Jiménez-Melero, R., Galotti, A., García-Muñoz, E., Lendínez, M.L., Ortega, F. (2006): Ecological studies in Alto Guadalquivir wetlands: a first step towards the application of conservation plans. Limnetica 25: 95-106.

Houlahan, J.E., Findlay, C.S., Schmidt, B.R., Meyer, A.H., Kuzmin, S.L. (2000): Quantitative evidence for global amphibian population declines. Nature 404: 752-755.

Hutchens, S.J., DePerno, C.S. (2009): Efficacy of sampling techniques for determining species richness estimates of reptiles and amphibians. Wildl. Biol. 15: 113-122.

Iturondobeitia, J., Caballero, A., Arroyo, J. (2004): Avances en la utilización de los ácaros oribátidos como indicadores de las condiciones edáficas. Munibe 21: 70-91. 
IUCN. (2010): The IUCN Red List of Threatened Species. Retrieved 12 December, 2016, from www.iucnredlist.org Kaczor, S.A., Harnett, D.C. (1990): Gopher tortoise (Gopherus polyphemus) effects on soils and vegetation in a Florida Sandhill community. Am. Midl. Nat. 123: 100-111.

Kilburn, V.L., Ibáñez, R., Green D.M. (2011): Reptiles as potential vectors and hosts of the amphibian pathogen Batrachochytrium dendrobatidis in Panama. Dis. Aquat. Organ. 97: 127-134.

Lizana, M., Barbadillo, L.J. (1997): Legislación, protección y estado de conservación de los anfibios y reptiles españoles. In: Distribución y Biogeografía de los Anfibios y Reptiles en España y Portugal, pp. 477-516. Pleguezuelos, J.M., Ed, Universidad de Granada and Asociación Herpetológica Española, Granada.

Mann, R.M., Hyne, R.V., Choung, C.B., Wilson, S.P. (2009): Amphibians and agricultural chemicals: review of the risks in a complex environment. Environ. Poll. 157: 2903-2927.

Márquez, R., Lizana, M. (2002): Conservación de anfibios y reptiles en España. In: Atlas y Libro Rojo de los Anfibios y Reptiles de España, pp. 417-453. Pleguezuelos, J.M., Márquez, R., Lizana, M., Eds, Ministerio de Medio Ambiente, Madrid.

McCallum, M.L. (2007): Amphibian decline or extinction? Current declines dwarf background extinction rate. J. Herpetol. 41: 483-491.

Overmann, S.R., Krajicek, J.J. (1995): Snapping turtles (Chelydra serpentina) as biomonitors of lead contamination of the big river in Missouri's old lead belt. Environ. Toxicol. Chem. 14: 689-695.

Pianka, E.R. (1967): On lizard species diversity: North American flatland deserts. Ecology 48: 333-351.

Pimm, S.L., Jenkins, C.N., Abell, R., Brooks, T.M., Gittleman, J.L., Joppa, L.N., Raven, P.H., Roberts, C.M., Sexton, J.O. (2014): The biodiversity of species and their rates of extinction, distribution, and protection. Science 344: 1246752

Pleguezuelos, J.M. (2002): Distribución y biogeografía de los anfibios y reptiles en España y Portugal. Monografías de Herpetología, 3. Universidad de Granada and Asociación Herpetológica Española, Granada.

Pleguezuelos, J.M., Márquez, R., Lizana, M. (2002): Atlas y Libro Rojo de los Anfibios y Reptiles de España. Dirección General de Conservación de la NaturalezaAsociación Herpetólogica Española, Madrid.

Ramírez-González, A. (2005): Ecología aplicada. Diseño y análisis estadístico. Universidad de Bogotá Jorge Tadeo Lozano, Bogotá.

Rey-Zamora, P.J., Gutiérrez, J.E., Valera, F., Ruiz, C. (2017): El olivar andaluz, ¿un bosque humanizado? Aldaba 41: 113-120.
Ripple, W.J., Wolf, C., Newsome, T.M., Hoffmann, M., Wirsing, A.J., McCauley, D.J. (2017): Extinction risk is most acute for the world's largest and smallest vertebrates. Proc. Nat. Ac. Sci. 114: 10678-10683.

Rockström, J., Steffen, W., Noone, K., Persson, A., Chapin III, F.S., Lambin, E.F., Lenton, T.M., Scheffer, M., Folke, C., Schellnhuber, H.J., Nykvist, B., de Wit, C.A., Hughes, T., van der Leeuw, S., Rodhe, H., Sörlin, S.; Snyder, P.K., Costanza, R., Svedin, U., Falkenmark, M., Karlberg, L., Corell, R.W., Fabry, V.J., Hansen, J., Walker, B., Liverman, D., Richardson, K., Crutzen, P., Foley, J.A. (2009): A safe operating space for humanity. Nature 461: 472-475.

Sagoff, M. (2013): Conservation Biology. In: The International Encyclopedia of Ethics, pp. 1055-1064. Blackwell Publishing, Ltd, Oxford.

Salvador, A., Pleguezuelos, J.M. (2002): Reptiles Españoles. Identificación, historia natural y distribución. Canseco editores, Talavera de la Reina, Toledo.

Santos, X., Cheylan, M. (2013): Taxonomic and functional response of a Mediterranean reptile assemblage to a repeated fire regime. Biol. Conserv. 168: 90-98.

SEO - Sociedad Española de Ornitología. (2008): Retrieved 19 October, 2016, from www.aitorgaston.com/seo.php

Simpson, E.H. (1949): Measurement of diversity. Nature 163: 688.

Soulé, M. (1985): What is the conservation Biology? BioScience 35: 727-734.

Sparling, D.W. (2003): A review of the role of contaminants in amphibian declines. In: Handbook of ecotoxicology, pp. 1099-1128. Hoffman, D., Rattner, B.A., Cairns, J., Eds, Lewis Publishers, Boca Raton.

Sparling, D.W., Bickham, J., Cowman, D., Fellers, G.M., Lacher, T., Matson, C.W., McConnell, L. (2015): In situ effects of pesticides on amphibians in the Sierra Nevada. Ecotoxicol. 24: 262-278.

Sparling, D.W., Bishop, C.A., Pauli, B.D., Money, S. (2000): Epilogue: lessons yet to be learned. In: Ecotoxicology of amphibians and reptiles, pp. 811-822. Sparling, D.W., Linder, G., Bishop, C.A., Eds, SETAC Press, Pensacola.

Stuart, S.N., Chanson, J.S., Cox, N.A., Young, B.E., Rodrigues, A.S.L., Fischman, D.L., Waller, R.W. (2004): Status and trends of amphibian declines and extinctions worldwide. Science 306: 1783-1786.

Tejedo, M. (2003): El declive de los anfibios. La dificultad de separar las variaciones naturales del cambio global. Munibe 16: 20-43.

Trochet, A., Moulherat, S., Calvez, O., Stevens, V., Clobert, J., Schmeller, D. (2014): A database of lifehistory traits of European amphibians. Biodivers. Data J2: e4123. 
Vera, J.A. (1994): Geología de Andalucía. Enseñanzas de la Tierra 2: 306-317.

Wright, A.J., Wardle, D.A., Callaway, R., Gaxiola, A. (2017): The overlooked role of facilitation in biodiversity experiments. TREE 32: 383-390. 